\title{
Do the Characteristics of Independent Directors and Supervisory Board Members Matter in China?
}

\author{
Hongmei $\mathrm{Xu}^{1}$, Jiang $\operatorname{Lin}^{1}$ \\ ${ }^{1}$ Lingnan (University) College, Sun Yat-sen University, China \\ Correspondence: Jiang Lin, Xingang xi Road 135, 510275, Guangzhou, China.
}

Received: June 30, 2016

Accepted: July 13, 2016

Online Published: August 15, 2016

doi:10.11114/bms.v2i3.1809

URL: http://dx.doi.org/10.11114/bms.v2i3.1809

\begin{abstract}
This paper investigates and compares the characteristics of independent directors and supervisory board members in Chinese listed firms. The occupational backgrounds of independent directors and supervisory board members in listed firms are very different. Besides, different firms have different preferences in employing independent directors and supervisory board members according to their demands. Moreover, the empirical results show that characteristics of independent directors and supervisory board members have no clear relationship with firm performance. No matter their professional backgrounds or age, the independent directors and supervisory board members do not have the authority to affect the decision making process of management. Thus they cannot really contribute to firm performance.
\end{abstract}

Keywords: board of directors, corporate governance, firm performance, independent directors, supervisory board members

JEL-Codes: G30, G34, M51, O16, P31

\section{Introduction}

The current Chinese corporate governance framework is a result of the establishment of a modern enterprise system in China. With the reformation of state-owned enterprises and the fast growth of private enterprises, the Chinese authorities have lead all market participants to build a corporate governance system that suits China's actual situation. According to the self-assessment by the China Securities Regulatory Commission (cited by OECD 2011, p.18), listed firms are mainly structured by the following four organs:

"The general shareholders' meeting is the power and decision-making organ of the company and has decision making power concerning major issues. The board of directors is the operational implementation organ of the company, being responsible to the general shareholders' meeting, and has the decision making power concerning management issues under the authority of general shareholders' meeting, set up special committees, such as strategy committee, auditing committee, nomination committee, remuneration and appraisal committee. The management is responsible to the board of directors, and is in charge of the daily operation and management of the company. The supervisory board is the supervision organ of the company, which supervises whether directors and managers violate laws or articles of association of the company when accomplishing corporate duties, and is entitled to inspect company's finance."

What should be emphasized here is that, in normal listed firms, the general shareholders' meeting nominates and selects the members of the directory board and supervisory board. However, due to China's special situation, the State-owned Assets Supervision and Administration Commission (SASAC) also exercises great power in nominating directory board members and supervisory board members in state-owned listed firms.

From the above description, it is clear that Chinese listed firms employ a two-tier board system, which includes both a board of directors and a supervisory board (see Figure 1). Nevertheless, different from the typical German two-tier board system, the Chinese Company Law (Chapter 4, Section 4, Article 123 in the revised version from 2005) regulates that listed firms should recruit at least one third of independent directors on their directory board. However, independent directors and supervisory board members have almost the same responsibilities to monitor and to advice the management in the US one-tier board and in the German two-tier board systems. Therefore, in China's case, it is interesting to explore the differences between independent directors and supervisory board members regarding their characteristics. Further one can explore how much the characteristics of independent directors and supervisory board members affect firm performance. 


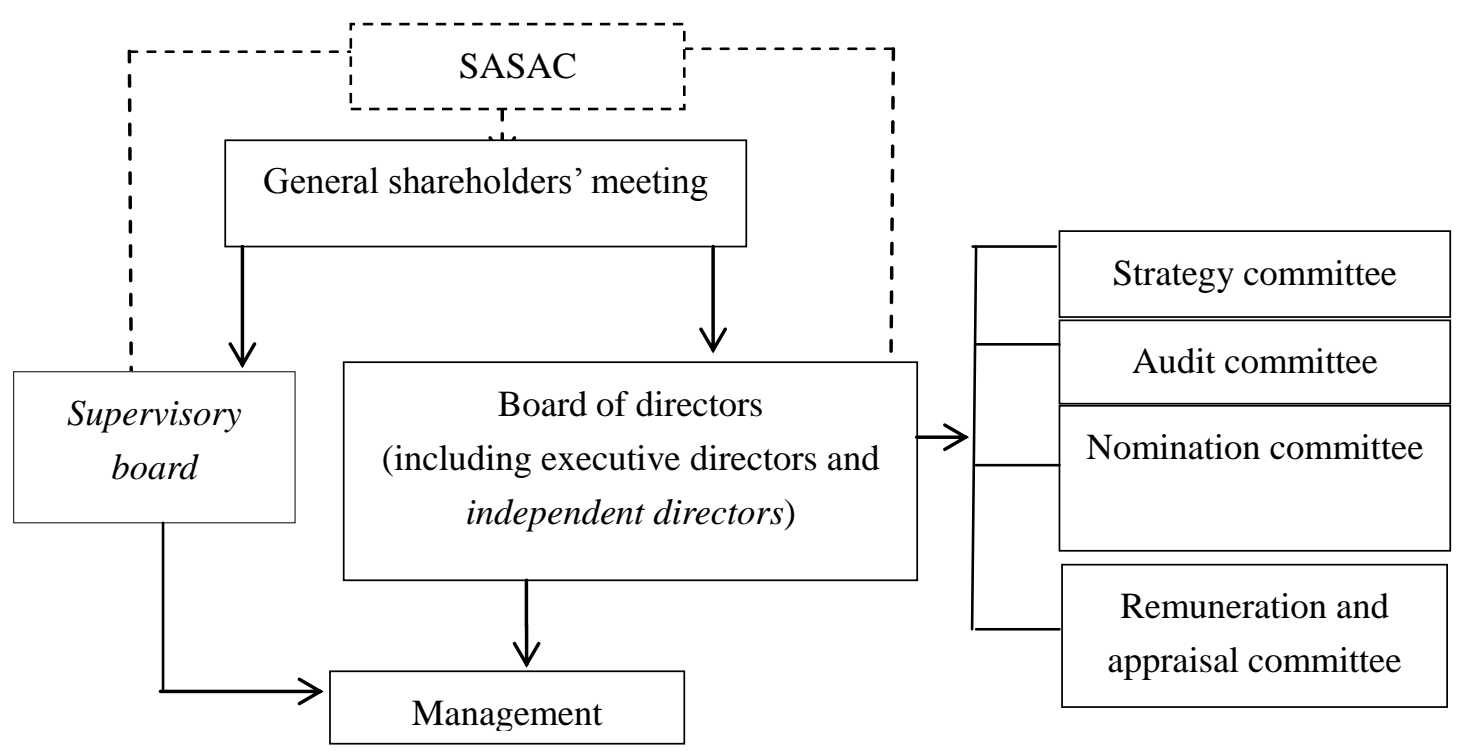

Figure 1. The Chinese Corporate Governance Framework ${ }^{1}$

It seems that the Chinese corporate governance system does not coordinate the relationship between independent directors and supervisory board very well. The functions of independent directors and supervisory board members are largely overlapping. Therefore, one can identify clearly only minor differences between them: Independent directors should focus more on monitoring inside directors and management. For example, they should prevent senior managers' self-dealing on compensation and constrain senior managers' power to convene board meetings and shareholders' meetings. Besides, they also have the task to keep the auditing process from being controlled by inside directors and to ensure the fairness of party transactions. Instead, supervisory board members should supervise firms' financial positions and the behavior of the senior management. If laws, regulations, firm articles and resolutions of shareholders' meetings are violated, the supervisory board should protect the legitimate rights and interests of listed firms and their shareholders. As shown, the Chinese law and regulations only provide a vague understanding of the differences between independent directors and supervisory board members in listed firms. An empirical study is helpful to get a deeper understanding of their different characteristics and how much these characteristics can benefit listed firms.

Most studies on Chinese corporate governance discuss the functions and the characteristics of independent directors and supervisory board members separately. On the one hand, academic research identifies independent directors as outsiders and most studies focus on effects of independency or size of the directory board on firm performance. Sometimes, age, gender, and educational backgrounds of independent directors are also included in these discussions (Gantenbein and Volonte, 2012, Erhardt et al., 2003). However, independent directors' characteristics like occupational backgrounds are rarely discussed by academia. On the other hand, in most studies, the Chinese supervisory board is argued to be weak and to have no relationship with firm performance (Dahya et al., 2001, Tian, 2009, and Liu et al., 2010). Besides, the characteristics of supervisory board members have not yet received much attention from academia. Therefore, a comparison of the characteristics of independent directors and supervisory board members in Chinese listed firms is worthwhile. Further, although some theoretical studies have argued that both the independent directors and supervisory board are ineffective under China's special institutional environment, it is necessary to provide empirical evidence.

Firstly, this paper investigates the characteristics of independent directors and supervisory board members respectively. For example, most independent directors are scholars while most supervisory board members are current executives. Secondly, this paper provides a comparison of the characteristics of independent directors and supervisory board members in different firms with different sizes, equity status and industries. It is found that different firms have different preferences in choosing independent directors and supervisory board members. The examined characteristics in this paper are the age and occupational backgrounds of independent directors and supervisory board members. Thirdly, using a relatively large data set, this paper makes a range of OLS regressions to test the effects of these characteristics on firm performance. It turns out that, in China's case, the characteristics of independent directors and supervisory

\footnotetext{
${ }^{1}$ Own figure on the basis of OECD (2011), p. 18. SASAC refers to State-owned Assets Supervision and Administration Commission. The dashed arrow line and text box show that in state-owned firms SASAC also nominate the members of the directory board and the supervisory board.
} 
board members do not really affect firm performance. The underlying reasons will be discussed.

The rest of the paper is structured as follows. Section 2 describes the main hypotheses. Section 3 provides a data description while section 4 summarizes statistics. In section 5, empirical analyses and results will be shown. Section 6 includes a discussion and policy implications.

\section{Literature and Hypotheses}

In some Asian countries, scholars are one of the largest groups of independent or outside directors in listed firms. For example, Choi et al. (2007) find that, in Korea, 25\% of firms appoint scholars as outside directors. Tan et al. (2007) claim that about $40 \%$ of independent directors are scholars in Chinese firms. The data sample in this paper also shows that $40 \%$ of independent directors are scholars. According to Liao (2009), by recruiting famous scholars firms tend to seek valuable advice and send out signals to the market that they wish to improve their corporate governance. On the one hand, most of these scholars come from business administration departments, economics departments or other departments that relate to the firms' business scope. So they are supposed to provide professional advice benefiting the respective firms. On the other hand, famous scholars are highly respected in Asian countries. Investors and the public will trust listed firms more if they have famous scholars as board members. They believe that famous scholars have strong incentives to supervise listed firms in order to keep and improve their reputation. According to these arguments, the following hypotheses can be formulated:

H1a: Scholars as independent directors have a positive impact on firm performance.

H1b: Scholars as supervisory board members have a positive impact on firm performance.

It is argued that outside directors with governmental work background can benefit firms due to their knowledge of government procedures and their insights into predicting government actions (Agrawal and Knoebe, 2001). In Japan, firms specialized in public projects appoint more government bureaucrats as outside directors (Miwa and Ramseyer, 2005). According to Choi et al. (2007), Korean Chaebol firms tend to appoint executives of affiliate firms or individuals with political connections as outside directors. Hillman (1999) also reports that politically connected board members have positive and significant effects on market based firm performance. In China, it is assumed that listed firms prefer to have political connections in order to take advantage when borrowing from banks or receiving government sponsoring on preferential terms (Bai et al., 2004). This paper defines independent directors and supervisory board members with political connections as retired government officials. 2

H2a: Retired government officials as independent directors have a positive impact on firm performance.

H2b: Retired government officials as supervisory board members have a positive impact on firm performance.

Some researchers claim that professional expertise of board members can influence their understanding of business transactions and improve their decisions (Kesner 1988). The influence of bankers and other directors with financial experiences is frequently investigated by researchers. For example, Byrd et al. (2005) insist that commercial bankers can provide expertise for the management and enhance the access to capital. Krosner and Strahan (2001) find that bankers and other financial experts on corporate boards are associated with stable stock returns. Accountants and auditors are familiar with financial reports and the company can also benefit from their professional skills. Agrawal and Knoeber (2001) suggest that large firms and firms with higher environmental regulation costs tend to recruit more lawyers as directors. All of the examples indicate that listed firms will recruit independent directors and supervisory board members with special professional backgrounds to improve firm performance.

H3a: Independent directors with professional background in specific fields have a positive impact on firm performance.

H3b: Supervisory board members with professional background in specific fields have a positive impact on firm performance.

Executives have outstanding authority and experience that are well suited for monitoring and advising the management. For example, outside CEOs are appointed by firms in order to benefit from their reputation and to assure the public that the firm is doing well (Fahlenbrach, 2009). Executives themselves also prefer to serve as independent directors and supervisory board members in other firms in order to build additional networks and to enhance prestige. Brickley et al. (1999) also demonstrate that by appointing former executives as directors, firms are more likely to have a good accounting performance. In this paper, executives refer to former executives and current ones.

\footnotetext{
${ }^{2}$ Some researches argue that directors who have a party membership can be considered as having a political background. This might be too general. It is sure that directors with political backgrounds have party memberships but not all party members have a political background. However, those who have worked in a government organization definitely have a political background.
} 
H4a: Executives as independent directors have a positive impact on firm performances.

H4b: Executives as supervisory board members have a positive impact on listed firms.

There are different opinions on the effect of age on firm performance. Some scholars argue that older board members might benefit the firm because of more business experience. Others insist that younger board members are more beneficial. Rose (2005) reports that boards having a younger average age outperform older boards. The explanation for younger boards' superior firm performance is that the age of the directors may influence the risks and decisions they pursue. For example, Zajac and Westphal (1996) suggest that the age of individuals could affect their openness to new ideas. Younger directors may be more willing to take risks and be more innovative (Hambrick et al., 1984, Grimm et al., 1991). Although younger directors have less experience, they have superior technical knowledge resulting from better and fresher education (Bantel et al., 1989). This paper agrees with the latter opinion that younger independent directors and supervisory board members are more efficient.

H5a: Younger independent directors have a positive impact on firm performance.

H5b: Younger supervisory board members have a positive impact on firm performance.

\section{Data Description}

In this paper, the SSE (Shanghai Stock Exchange) 180 Index Companies are used as sample data. 3 Some firms in the financial sector (banks, insurance companies, security companies and other financial firms) are excluded because of their different disclosure requirements in China. Finally, there are 151 firms left in the data set. Most of the financial data and all characteristics information of independent directors and supervisory board members are collected from the firms' annual reports. One year stock return is collected from Bloomberg. Industry data is collected from the website of Shanghai Stock Exchange. All collected data is derived from the financial year 2011.

\subsection{Dependent Variables}

Firm performance is measured in many ways in the existing literature. In this paper, ROE (return on equity) is used as accounting measurement while Rtn (one year stock return) is used as a market measure to represent firm performance. ROE equals a fiscal year's after-tax income divided by total equity. Rtn is the percentage of stock market return for the last year. EPS (earnings per share) will be used to check the robustness of the regression results. It is calculated as net income minus dividends on preferred stock and then divided by average outstanding shares.

\subsection{Independent Variables}

\subsubsection{Variables of Interest}

Based on previous literature and the specific situation in the Chinese corporate governance system, this paper collects 11 characteristics of independent directors (see Table 1) and 15 characteristics of supervisory board members (see Table 2). Compared to independent directors, 4 additional characteristics of supervisory board members are collected. They are insiders, outsiders, union representatives and party representatives.

Insiders and outsiders are selected because the Chinese company law regulates that listed firms should recruit one third of employee representatives on the supervisory board. However, how much outsiders should be on the supervisory board is not clearly stated by the law. It is possible that the Chinese supervisory board is insider-controlled. So it makes sense to investigate this situation.

The other two variables, union representatives and communist party representatives, are typical in China's situation concerning supervisory board members. Before the corporate reforms, unions and party affiliations played very important roles in supervising state-owned enterprises. Since the early 1990s, when the western corporate governance mechanism has been introduced to China, these two groups have gradually lost their importance. However, at present, there still exist many of them in state-owned enterprises and in some companies that used to be state-owned enterprises. Moreover, in these firms, union and party representatives normally occupy seats on the supervisory board. So it is necessary to put these two variables into the study. In this paper, the variable union representatives refers to the chairman or vice chairman of the union. The variable communist party representatives refers to the secretary or vice secretary of the party affiliations. They are also counted as occupations.

\footnotetext{
3 The list of SSE 180 index companies were extracted from the website of Shanghai Stock Exchanges on September 2012. Every six months, the SSE 180 index companies will be changed. The link is http://www.sse.com.cn/market/sseindex/indexlist/s/i000010/const_list.shtml to the Chinese website.
} 
Table 1. Summary Statistics for Independent Directors

\begin{tabular}{|c|c|c|c|c|c|}
\hline Definition of variables & Mean & Median & Min & Max & S.D. \\
\hline \multicolumn{6}{|l|}{ Dependent Variables } \\
\hline Return on equity (\%) (ROE) & 16.90 & 14.52 & -25.34 & 84.67 & 13.56 \\
\hline Annual stock return (\%) (Rtn) & 1.57 & -5.95 & -45.93 & 173.29 & 36.62 \\
\hline Earnings per share (EPS) & 0.77 & 0.51 & -1.02 & 8.44 & 0.91 \\
\hline \multicolumn{6}{|l|}{ Independent Variables } \\
\hline Age & 56.32 & 55.33 & 40.66 & 68.60 & 6.03 \\
\hline Scholars $(\%)$ & 40.10 & 33.33 & 0.00 & 100.00 & 30.01 \\
\hline Accountants $(\%)$ & 14.36 & 00.0 & 0.00 & 66.67 & 17.10 \\
\hline Retired government officials (\%) & 10.80 & 0.00 & 0.00 & 100.00 & 18.37 \\
\hline Current executives (\%) & 10.58 & 0.00 & 0.00 & 66.67 & 18.04 \\
\hline Lawyers (\%) & 8.13 & 0.00 & 0.00 & 66.67 & 13.79 \\
\hline Former executives (\%) & 5.60 & 0.00 & 0.00 & 66.67 & 13.12 \\
\hline Commercial bankers $(\%)$ & 0.92 & 0.00 & 0.00 & 33.33 & 5.17 \\
\hline Auditors (\%) & 0.52 & 0.00 & 0.00 & 33.33 & 3.74 \\
\hline Consultants (\%) & 0.35 & 0.00 & 0.00 & 33.33 & 3.15 \\
\hline Others $(\%)$ & 8.64 & 0.00 & 0.00 & 66.67 & 15.47 \\
\hline \multicolumn{6}{|l|}{ Control Variables } \\
\hline Firm size & 30655.11 & 9185.00 & 53.00 & 552810.00 & 66800.22 \\
\hline Log (Firm size) & 9.05 & 9.13 & 3.97 & 13.22 & 1.76 \\
\hline Debt ratio $(\%)$ & 54.08 & 55.40 & 7.82 & 85.46 & 17.59 \\
\hline Directory board size & 10.12 & 9.00 & 5.00 & 18.00 & 2.49 \\
\hline Board independence $(\%)$ & 38.52 & 36.36 & 27.78 & 75.00 & 8.28 \\
\hline Supervisory board size & 4.56 & 5.00 & 3.00 & 11.00 & 1.68 \\
\hline \multicolumn{6}{|l|}{ Industry } \\
\hline Largest shareholder is state & 0.75 & 1.00 & 0.00 & 1.00 & 0.44 \\
\hline $\begin{array}{l}\text { Top } 5 \text { shareholders include } \\
\text { foreign shareholders }\end{array}$ & 0.16 & 0.00 & 0.00 & 1.00 & 0.37 \\
\hline
\end{tabular}

Note: The table presents the mean, median, minimum (Min) and maximum (Max) values as well as standard deviation (S.D.) for each variable. The variables scholars, accountants, retired government officials, current executives, lawyers, former executives, commercial bankers, auditors, consultants and others are calculated as their numbers on boards divided by the total number of independent directors and then multiplied by 100 . The variable board independence is calculated as the number of independent directors divided by the directory board size and then multiplied by 100 . 
Table 2. Summary Statistics for Supervisory Board Members

\begin{tabular}{|c|c|c|c|c|c|}
\hline Definition of variables & Mean & Median & Min & $\operatorname{Max}$ & S.D. \\
\hline \multicolumn{6}{|l|}{ Dependent Variables } \\
\hline Return on equity (\%) (ROE) & 16.90 & 14.52 & -25.34 & 84.67 & 13.56 \\
\hline Annual stock return (\%) (Rtn) & 1.57 & -5.95 & -45.93 & 173.29 & 36.62 \\
\hline Earnings per share (EPS) & 0.77 & 0.51 & -1.02 & 8.44 & 0.91 \\
\hline \multicolumn{6}{|l|}{ Independent Variables } \\
\hline Age & 48.75 & 49.33 & 34.00 & 62.40 & 4.75 \\
\hline Current executives (\%) & 31.11 & 33.33 & 0.00 & 100.00 & 29.08 \\
\hline Accountants (\%) & 15.95 & 14.29 & 0.00 & 100.00 & 18.33 \\
\hline Party representatives (\%) & 15.17 & 11.11 & 0.00 & 100.00 & 21.51 \\
\hline Union representatives (\%) & 8.20 & 16.67 & 0.00 & 66.67 & 12.94 \\
\hline Auditors (\%) & 7.01 & 0.00 & 0.00 & 40.00 & 11.72 \\
\hline $\begin{array}{l}\text { Retired government officials } \\
(\%)\end{array}$ & 3.12 & 0.00 & 0.00 & 40.00 & 9.11 \\
\hline Former executives (\%) & 2.13 & 0.00 & 0.00 & 66.67 & 8.50 \\
\hline Scholars $(\%)$ & 1.11 & 0.00 & 0.00 & 37.50 & 5.50 \\
\hline Lawyers (\%) & 1.11 & 0.00 & 0.00 & 20.00 & 4.27 \\
\hline Commercial bankers (\%) & 0.00 & 0.00 & 0.00 & 0.00 & 0.00 \\
\hline Consultants (\%) & 0.00 & 0.00 & 0.00 & 0.00 & 0.00 \\
\hline Others $(\%)$ & 15.10 & 0.00 & 0.00 & 100.00 & 21.51 \\
\hline Insiders (\%) & 93.71 & 100.00 & 33.33 & 100.00 & 13.90 \\
\hline Outsiders (\%) & 6.29 & 0.00 & 0.00 & 66.67 & 13.63 \\
\hline \multicolumn{6}{|l|}{ Control Variables } \\
\hline Firm size & 30655.11 & 9185.00 & 53.00 & 552810.00 & 66800.22 \\
\hline Log (Firm size) & 9.05 & 9.13 & 3.97 & 13.22 & 1.76 \\
\hline Debt ratio (\%) & 54.08 & 55.40 & 7.82 & 85.46 & 17.59 \\
\hline Directory board size & 10.12 & 9.00 & 5.00 & 18.00 & 2.49 \\
\hline Board independence $(\%)$ & 38.52 & 36.36 & 27.78 & 75.00 & 8.28 \\
\hline Supervisory board size & 4.56 & 5.00 & 3.00 & 11.00 & 1.68 \\
\hline \multicolumn{6}{|l|}{ Industry } \\
\hline Largest shareholder is state & 0.75 & 1.00 & 0.00 & 1.00 & 0.44 \\
\hline $\begin{array}{l}\text { Top } 5 \text { shareholders include } \\
\text { foreign shareholders }\end{array}$ & 0.16 & 0.00 & 0.00 & 1.00 & 0.37 \\
\hline
\end{tabular}

Note: The table presents the mean, median, minimum (Min) and maximum (Max) values as well as standard deviation (S.D.) for each variable. The variables: current executives, accountants, party representatives, union representatives, auditors, retired government officials, former executives, scholars, lawyers, commercial banker, consultants, and others are calculated as their numbers on boards divided by the total number of independent directors and then multiplied by 100.

\subsubsection{Control Variables}

Apart from the variables of primary interest, this paper also controls for listed firms' characteristics and their governance characteristics which are expected to influence firm performance. Firms' characteristics are firm size, debt ratio, industry, and the equity status of listed firms. The governance characteristics are directory board size, supervisory board size, and board independence respectively. Two dummy variables are used to reflect the equity status of firms. The variable largest shareholder is state equals 1 if the firm's largest shareholder is the state, otherwise it equals 0 . The 
variable top 5 shareholders include foreign shareholders equals 1 if one or several of the firm's top 5 largest shareholders are foreign shareholders, otherwise it equals 0 . Moreover, the number of employees represents the firm size. The variable $\log$ (firm size) is the log function of firm size. Instead of firm size, log (firm size) is used in the regressions to deal with skewness. Board independence is the percentage of independent directors in the board of directors. The variable industry includes 9 industries in accordance to GICS (global industry classification standard).

\section{Summary Statistics}

Table 1 and Table 2 provide the summary data of characteristics of independent directors and supervisory board members. Firstly, the average age of the supervisory board members is lower than of the independent directors ( 48.75 vs. 56.32). Secondly, the occupational composition of independent directors and supervisory board members are very different. Thirdly, the board independency and the supervisory board size in Chinese listed firms are much smaller than in the USA or Germany.

Table 1 presents the summary of independent directors' characteristics. The top 5 main occupations are scholars $(40.10 \%)$, accountants $(14.36 \%)$, retired government officials $(10.80 \%)$, current executives $(10.58 \%)$ and lawyers (8.13\%). Surprisingly, in Chinese listed firms, commercial bankers, auditors, and consultants account for very small percentages among independent directors with $0.92 \%, 0.52 \%$ and $0.35 \%$ respectively. Table 2 contains a summary of supervisory board members' characteristics. The top 5 main occupations of supervisory board members are very different. They are current executives (31.11\%), accountants (15.95\%), party representatives (15.17\%), union representatives $(8.20 \%)$ and auditors $(7.01 \%)$, whereas scholars and lawyers only have a few percentages on the supervisory board, about $1.11 \%$ for each. Moreover, commercial bankers and consultants are not at all on Chinese supervisory boards although they are main components on either supervisory board or as independent directors in western countries. Lastly, accountants is the only variable that has very little percentage difference in independent directors and on supervisory boards $(14.36 \%$ vs. $15.95 \%)$.

The average number on the board of directors is 10.12 and board independence is $38.52 \%$. The size of the board of directors in China is smaller than the average US board of directors and the Chinese board independency is lower. 4 In this context, the lower board independency illustrates that the Chinese board of directors may have an insider-control problem. The percentage $38.52 \%$ is only a little bit higher than prescribed $33.33 \%$, which indicates that listed firms may have independent directors just to satisfy CSRC' regulations. The average number of supervisory board members is 4.56 , which is also only a little bit more than the provisions of the Chinese Company Law (which regulates that the supervisory board should have at least 3 members). Compared to German supervisory boards, Chinese supervisory boards are much smaller.5 Moreover, on the supervisory board, insiders have a percentage of $93.71 \%$, which indicates that the Chinese supervisory board also suffers from an insider-control problem.

Table 3 and Table 4 present the occupations of independent directors and supervisory board members in firms with different sizes and equity status. In most of the cases, it can be seen that large firms and state-owned firms have similar preferences while small firms and non-state-owned firms have other but between them also quite similar preferences in selecting both independent directors and supervisory board members.

Table 3 shows that large firms and state-owned firms employ less scholars as independent directors than small firms and non-state-owned firms (32.50\% and $37.45 \%$ vs. $38.29 \%$ and $47.98 \%$ ). This indicates that small firms and non-state-owned firms tend to have more scholars as independent directors in order to impress the public and investors respectively. Moreover, in large firms and state-owned firms, there are nearly 3 times more retired government officials that serve as independent directors than in small firms and non-state-owned firms. This is consistent with China's institutional situation, in which large firms and state-owned firms have stronger political connections. Besides, former executives as independent directors account for higher percentages in large firms and state-owned firms. In contrast, current executives have lower percentages in large firms and state-owned firms.

\footnotetext{
${ }^{4}$ According to an investigation by Fortune magazine, in the top 1.000 US firms the average board scale is 11. Normally, independent directors occupy 9 of the seats (board independency is more than $80 \%$ ) on the board of directors.

${ }^{5}$ Depending on the number of employees, the size of the supervisory board is by German law at least 12, 16, or 20 for companies with domestic employment ranging from 2,000 to less than 10,000, 10,000 to less than 20,000 and more than 20,000 respectively.
} 
Table 3. Data Description of Independent Directors' Characteristics (classified by firm size and equity status)

\begin{tabular}{|c|c|c|c|c|c|}
\hline & Scholars & $\begin{array}{l}\text { Commercial } \\
\text { bankers }\end{array}$ & $\begin{array}{l}\text { Retired } \\
\text { government } \\
\text { officials }\end{array}$ & Accountants & Auditors \\
\hline \multicolumn{6}{|l|}{ By firm size } \\
\hline Large firms ( $\geq \mathrm{p} 75$ ) & 32.50 & 1.40 & 15.97 & 13.99 & 0.53 \\
\hline Small firms $(\leq \mathrm{p} 25)$ & 38.29 & 0.53 & 5.70 & 17.59 & 0.00 \\
\hline \multicolumn{6}{|l|}{ By equity status } \\
\hline State-owned firms & 37.45 & 0.65 & 12.94 & 13.63 & 0.69 \\
\hline \multirow[t]{2}{*}{ Non-state-owned firms } & 47.98 & 1.75 & 4.43 & 16.54 & 0.00 \\
\hline & Lawyers & $\begin{array}{l}\text { Former } \\
\text { executives }\end{array}$ & $\begin{array}{l}\text { Current } \\
\text { executives }\end{array}$ & Consultants & Others \\
\hline \multicolumn{6}{|l|}{ By firm size } \\
\hline Large firms $(\geq \mathrm{p} 75)$ & 4.77 & 8.62 & 13.20 & 0.88 & 8.14 \\
\hline Small firms $(\leq \mathrm{p} 25)$ & 10.35 & 3.80 & 14.90 & 0.00 & 8.86 \\
\hline \multicolumn{6}{|l|}{ By equity status } \\
\hline State-owned firms & 8.58 & 6.56 & 10.27 & 0.47 & 8.75 \\
\hline Non-state-owned firms & 6.80 & 2.72 & 11.49 & 0.00 & 8.29 \\
\hline
\end{tabular}

Note: Here large firms refer to those whose firm size $\geq$ p 75 and small firms refer to those whose firm size $\leq \mathrm{p} 25$. All the given data is the mean value and is measured by percentage.

Table 4 presents the occupations of supervisory board members in firms with different sizes and equity status. For scholars, retired government officials and current executives, similar rules are applied in choosing supervisory board members by large firms and state-owned firms on the one hand and small firms and non-state-owned firms on the other hand. For example, the percentages of scholars as supervisory board members in large firms and state-owned firms are larger than in small firms and non-state-owned firms (2.13\% and $1.19 \%$ vs. $0.88 \%$ and $0.89 \%)$. This means small firms and non-state-owned firms need more scholars as supervisory board members to convince the public. However, it is found that there are more former executives on the supervisory board in small firms and non-state-owned firms. Taking into consideration that most of these small firms and non-state-owned firms are family business, the discussed results make a lot of sense. In most occasions, former executives are also the founders of these firms, indicating that small firms and non-state-owned firms might suffer more from the insider-control problem. 
Table 4. Data Description of Supervisory Board Members' Characteristics (classified by firm size and equity status)

\begin{tabular}{|c|c|c|c|c|c|}
\hline & Scholars & $\begin{array}{l}\text { Commercial } \\
\text { bankers }\end{array}$ & $\begin{array}{l}\text { Retired } \\
\text { government } \\
\text { officials }\end{array}$ & Accountants & Auditors \\
\hline \multicolumn{6}{|l|}{ By firm size } \\
\hline Large firms $(\geq \mathrm{p} 75)$ & 2.13 & 0.00 & 5.54 & 15.82 & 7.19 \\
\hline Small firms $(\leq \mathrm{p} 25)$ & 0.88 & 0.00 & 2.28 & 17.37 & 4.65 \\
\hline \multicolumn{6}{|l|}{ By equity status } \\
\hline State-owned firms & 1.19 & 0.00 & 3.70 & 16.14 & 7.48 \\
\hline \multirow[t]{2}{*}{ Non-state-owned firms } & 0.89 & 0.00 & 1.40 & 15.35 & 5.61 \\
\hline & Lawyers & $\begin{array}{l}\text { Former } \\
\text { executives }\end{array}$ & $\begin{array}{l}\text { Current } \\
\text { executives }\end{array}$ & Consultants & Others \\
\hline \multicolumn{6}{|l|}{ By firm size } \\
\hline Large firms $(\geq \mathrm{p} 75)$ & 1.85 & 1.97 & 20.40 & 0.00 & 13.38 \\
\hline Small firms $(\leq \mathrm{p} 25)$ & 0.00 & 2.63 & 41.97 & 0.00 & 16.44 \\
\hline \multicolumn{6}{|l|}{ By equity status } \\
\hline State-owned firms & 1.30 & 1.67 & 26.32 & 0.00 & 14.28 \\
\hline \multirow[t]{2}{*}{ Non-state-owned firms } & 0.52 & 3.51 & 45.35 & 0.00 & 17.54 \\
\hline & $\begin{array}{l}\text { Union } \\
\text { representative } \\
\mathrm{s}\end{array}$ & $\begin{array}{l}\text { Party } \\
\text { representatives }\end{array}$ & Insiders & Outsiders & \\
\hline \multicolumn{6}{|l|}{ By firm size } \\
\hline Large firms $(\geq \mathrm{p} 75)$ & 12.22 & 19.49 & 93.12 & 6.44 & \\
\hline Small firms $(\leq \mathrm{p} 25)$ & 3.20 & 10.57 & 95.43 & 3.68 & \\
\hline \multicolumn{6}{|l|}{ By equity status } \\
\hline State-owned firms & 9.83 & 18.09 & 93.95 & 5.39 & \\
\hline Non-state-owned firms & 3.33 & 6.49 & 92.98 & 7.02 & \\
\hline
\end{tabular}

Note: Here large firms refer to those whose firm size $\geq$ p75 and small firms refer to those whose firm size $\leq$ p25. All the given data is the mean value and is measured by percentage.

Table 5 and Table 6 present the occupations of independent directors and supervisory board members in different industries. In most occasions firms in traditional industries have similar preferences while firms in emerging industries have other similar preferences in recruiting both independent directors and supervisory board members. To simplify the description, the following two paragraphs will describe the results of both the energy and technology industries as representative for traditional and emerging industries.

Table 5 shows that firms in the energy industry (38.64\%) choose less scholars as independent directors than firms in the information industry $(46.88 \%)$. This indicates that firms in emerging industries tend to recruit more scholars as independent directors in order to show to the public that they have better firm performance. Besides, firms in the energy industry choose nearly 5 times more retired government officials as independent directors than firms in the information industry. This shows that firms in traditional industries have stronger political connections. Moreover, former executives in the energy industry $(9.70 \%)$ account for a larger percentage than in the information industry $(0.00 \%)$. However, current executives have similar percentages $(9.70 \%$ vs. $8.33 \%)$ in both industries. 
Table 5. Data Description of Independent Directors' Characteristics (classified by industry)

\begin{tabular}{|c|c|c|c|c|c|}
\hline & Scholars & $\begin{array}{l}\text { Commercial } \\
\text { bankers }\end{array}$ & $\begin{array}{l}\text { Retired } \\
\text { government } \\
\text { officials }\end{array}$ & Accountants & Auditors \\
\hline \multicolumn{6}{|l|}{ By industry } \\
\hline Energy & 38.64 & 0.00 & 16.67 & 10.76 & 0.00 \\
\hline Materials & 37.96 & 0.00 & 9.72 & 18.06 & 0.00 \\
\hline Industrials & 35.89 & 1.73 & 11.49 & 12.75 & 0.90 \\
\hline $\begin{array}{l}\text { Consumer } \\
\text { discretionary }\end{array}$ & 43.10 & 0.00 & 15.38 & 16.59 & 0.00 \\
\hline Consumer staples & 58.33 & 0.00 & 6.25 & 10.42 & 0.00 \\
\hline Health care & 61.90 & 0.00 & 13.10 & 16.67 & 0.00 \\
\hline Financials & 37.88 & 1.52 & 3.79 & 15.08 & 0.00 \\
\hline $\begin{array}{l}\text { Information } \\
\text { technology }\end{array}$ & 46.88 & 0.00 & 3.13 & 22.92 & 0.00 \\
\hline \multirow[t]{2}{*}{ Utilities } & 35.78 & 1.33 & 18.56 & 10.44 & 2.22 \\
\hline & Lawyers & $\begin{array}{l}\text { Former } \\
\text { executives }\end{array}$ & Current executives & Consultants & Others \\
\hline \multicolumn{6}{|l|}{ By industry } \\
\hline Energy & 9.70 & 9.70 & 9.70 & 0.00 & 4.85 \\
\hline Materials & 7.87 & 3.70 & 10.65 & 0.00 & 12.04 \\
\hline Industrials & 7.25 & 8.09 & 9.65 & 1.07 & 11.19 \\
\hline $\begin{array}{l}\text { Consumer } \\
\text { discretionary }\end{array}$ & 5.30 & 0.00 & 16.59 & 0.00 & 3.03 \\
\hline Consumer staples & 7.29 & 0.00 & 11.46 & 0.00 & 6.25 \\
\hline Health care & 8.33 & 0.00 & 0.00 & 0.00 & 0.00 \\
\hline Financials & 11.21 & 3.75 & 13.75 & 0.00 & 13.03 \\
\hline $\begin{array}{l}\text { Information } \\
\text { technology }\end{array}$ & 18.75 & 0.00 & 8.33 & 0.00 & 0.00 \\
\hline Utilities & 3.00 & 10.11 & 11.56 & 0.00 & 7.00 \\
\hline
\end{tabular}

Note: The variable industry covers 9 industries in accordance with GICS (global industry classification standard). All the given data is the mean value and is measured by percentage.

Table 6 shows the occupations of supervisory board members in different industries. Former executives have a larger percentage in information firms (7.74\%) than in energy firms $(4.85 \%)$. Current executives are also two times more common in information firms than in energy firms (42.41\% vs.17.35\%). This indicates that firms in emerging industries suffer more from the insider-control problem. 
Table 6. Data Description of Supervisory Board Members' Characteristics (classified by industry)

\begin{tabular}{|c|c|c|c|c|c|}
\hline & Scholars & Commercial bankers & $\begin{array}{l}\text { Retired } \\
\text { government } \\
\text { officials }\end{array}$ & Accountants & Auditors \\
\hline \multicolumn{6}{|l|}{ By industry } \\
\hline Energy & 3.03 & 0.00 & 2.27 & 17.64 & 6.69 \\
\hline Materials & 0.00 & 0.00 & 6.30 & 21.74 & 3.95 \\
\hline Industrials & 1.73 & 0.00 & 1.43 & 13.82 & 10.19 \\
\hline $\begin{array}{l}\text { Consumer } \\
\text { discretionary }\end{array}$ & 0.00 & 0.00 & 3.64 & 9.70 & 6.06 \\
\hline Consumer staples & 1.79 & 0.00 & 5.95 & 18.45 & 4.17 \\
\hline Health care & 0.00 & 0.00 & 0.00 & 12.38 & 9.52 \\
\hline Financials & 0.00 & 0.00 & 3.94 & 17.05 & 6.97 \\
\hline $\begin{array}{l}\text { Information } \\
\text { technology }\end{array}$ & 4.17 & 0.00 & 0.00 & 21.58 & 0.00 \\
\hline \multirow[t]{2}{*}{ Utilities } & 0.00 & 0.00 & 5.84 & 16.19 & 5.62 \\
\hline & Lawyers & Former executives & $\begin{array}{l}\text { Current } \\
\text { executives }\end{array}$ & Consultants & Others \\
\hline \multicolumn{6}{|l|}{ By industry } \\
\hline Energy & 2.15 & 4.85 & 17.35 & 0.00 & 24.72 \\
\hline Materials & 0.69 & 2.00 & 17.84 & 0.00 & 26.57 \\
\hline Industrials & 1.20 & 0.67 & 31.59 & 0.00 & 10.10 \\
\hline $\begin{array}{l}\text { Consumer } \\
\text { discretionary }\end{array}$ & 1.52 & 0.00 & 24.54 & 0.00 & 20.30 \\
\hline Consumer staples & 4.29 & 4.17 & 32.86 & 0.00 & 4.17 \\
\hline Health care & 0.00 & 0.00 & 51.43 & 0.00 & 4.76 \\
\hline Financials & 0.91 & 3.94 & 42.05 & 0.00 & 18.03 \\
\hline $\begin{array}{l}\text { Information } \\
\text { technology }\end{array}$ & 0.00 & 7.74 & 42.41 & 0.00 & 12.20 \\
\hline \multirow[t]{2}{*}{ Utilities } & 0.00 & 1.11 & 25.90 & 0.00 & 13.40 \\
\hline & $\begin{array}{l}\text { Union } \\
\text { representatives }\end{array}$ & Party representatives & Insiders & Outsiders & \\
\hline \multicolumn{6}{|l|}{ By industry } \\
\hline Energy & 13.92 & 7.37 & 95.83 & 4.17 & \\
\hline Materials & 6.30 & 14.61 & 96.54 & 3.46 & \\
\hline Industrials & 9.24 & 20.04 & 90.98 & 9.02 & \\
\hline $\begin{array}{l}\text { Consumer } \\
\text { discretionary }\end{array}$ & 15.45 & 18.79 & 96.36 & 3.64 & \\
\hline Consumer staples & 2.50 & 21.67 & 87.98 & 12.02 & \\
\hline Health care & 12.38 & 9.52 & 92.38 & 7.62 & \\
\hline Financials & 1.14 & 5.98 & 95.45 & 4.55 & \\
\hline $\begin{array}{l}\text { Information } \\
\text { technology }\end{array}$ & 3.87 & 8.04 & 100.00 & 0.00 & \\
\hline Utilities & 11.79 & 20.14 & 93.22 & 6.78 & \\
\hline
\end{tabular}

Note: The variable industry included 9 industries in accordance with GICS (global industry classification standard). All the given data is the mean value and is measured by percentage. 


\section{Empirical Results}

Before the regression analysis, Pearson's correlations were calculated to see whether there are high correlations $(\geq 0.7)$ between the variables. The variables insiders and supervisory board size have a correlation of 0.90 . However, the two variables are not studied in the same regression model. Therefore, the high correlation will not be a problem for the following empirical study. A correlation matrix is not presented in this paper but can be sent on demand. Other tests are also carried out to detect whether there are multicollinearity problems. Some of the variance inflations factors (vif) are much larger than 10. This indicates that some variables will create problems if they are in the same regression model. Due to this problem, some variables are deleted in the regression models in order to ensure the reliability of the regressions. The details will be introduced in the next paragraphs.

In this section, OLS regressions will be used to examine the effects of the characteristics of independent directors and supervisory board members on firm performance. ROE and Rtn are chosen as dependent variables that represent accounting and market measurements of firm performance. EPS will be used as dependent variable to test the robustness of the results. This paper suffers difficulties in choosing independent variables in the regression steps. Not all variables can be used but the following six independent variables have been chosen for the regression analysis: age (and $a^{2}{ }^{2}$ ), scholars, retired government officials, accountants, former executives and current executives. This is due to the fact that the high variance inflations factors $(\geq 10)$ of some variables could create multicollinearity problems, especially for variables with very low values such as commercial bankers $(0.92 \%)$, consultants $(0.35 \%)$, auditors $(0.52 \%)$ and lawyers $(1.11 \%)$. Their low values also show that these are not important occupations of independent directors and supervisory board members in Chinese listed firms. Furthermore, party representatives and union representatives will not be included in the comparison analysis. Only characteristics that both independent directors and supervisory board members have are analyzed.

Table 7 shows the effects of characteristics of independent directors on firm performance. In model 1, only the variables that are of primary interest in this paper are included. It turns out that all the characteristics have no significant effects on ROE. However, in this model, R2 is rather low, which indicates that these variables in model 1 are not the main factors that affect ROE. Therefore, in the next regression step, the control variables are added into model 2. As a result, R2 is relatively larger compared to model 1. Nevertheless, the results have not really improved. Except for the significantly positive effect of the accountants (at the level of 0.10), all other variables still have no significant effect on ROE. Further, the same is done for Rtn in model 3 and model 4. Unfortunately, there are no significant effects at all, even the significant effect of accountants has disappeared. Finally, EPS is used as dependent variable to test the robustness of the results. There are a few significant effects in model 5 and model 6 , for example the control variable debt ratio has a significant effect on EPS, but most of the results are consistent with the results in model 1 to 4 . To sum up, the regression results show that the characteristics of independent directors have no strong relations to firm performance.

Table 8 presents the effects of characteristics of supervisory board members on firm performance. Model 1 and model 2 show that the ratio of scholars has a significant negative effect on ROE (at the level of 5\%). However, this significant effect disappears in model 3 and model 4 when Rtn is used as the dependent variable. Other variables are found to have no highly significant effects on firm performance from model 1 to model 4 . Model 5 and model 6 use EPS as dependent variable to test the robustness of the results. They also show that none of the independent variables have highly significant effects on EPS except for the control variable debt ratio which has a significantly negative effect. In sum, the characteristics of supervisory board members also have no strong relations to firm performance.

The empirical results show that the characteristics of independent directors and supervisory board members do not really affect firm performance in Chinese listed firms. From an empirical point of view, the insignificant results in this paper maybe due to one of the following reasons. Empirical studies on the effects of directors' characteristics often have conflicting conclusions. On the one hand, the characteristics of directors are not the main determinants of firm performance. Studies choosing different kinds of measurements of firm performance normally obtained different results even if they studied the same characteristics. For example, Byrd et al. (2005) find that bankers have negative effects on debt ratios while Stearns and Mizruchi (1993) discover that the presence of bankers is positively associated with firms' short term borrowing. On the other hand, the definitions of the characteristics of the directors can vary. In this paper, the definitions of western countries are used which might not suit China's situation. This might create a bias of the results. Another explanation could be that some characteristics of directors might be sensitive to only certain measures of firm performance. For a study which explores a variety of characteristics, it would be difficult to find a certain measurement that is sensitive for each characteristic. Finally, independent directors, supervisory board members and their characteristics could just be not that important in China. 
Table 7. Effects of Characteristics of Independent Directors on Firm Performance

\begin{tabular}{|c|c|c|c|c|c|c|}
\hline \multirow{3}{*}{ Independent variables } & \multicolumn{6}{|c|}{ Dependent variables (for independent directors) } \\
\hline & \multicolumn{2}{|l|}{ ROE } & \multicolumn{2}{|l|}{ Rtn } & \multicolumn{2}{|l|}{ EPS } \\
\hline & Model 1 & Model 2 & Model 3 & Model 4 & Model 5 & Model 6 \\
\hline Age & $\begin{array}{l}3.6862 \\
(1.22)\end{array}$ & $\begin{array}{l}3.5173 \\
(1.06)\end{array}$ & $\begin{array}{l}-1.1543 \\
(-0.13)\end{array}$ & $\begin{array}{l}-3.8720 \\
(-0.43)\end{array}$ & $\begin{array}{l}0.3322 \\
(1.61)\end{array}$ & $\begin{array}{l}0.2780 \\
(1.29)\end{array}$ \\
\hline Age $^{2}$ & $\begin{array}{l}-0.3758 \\
(-1.44)\end{array}$ & $\begin{array}{l}-0.0373 \\
(-1.28)\end{array}$ & $\begin{array}{l}0.0046 \\
(0.06)\end{array}$ & $\begin{array}{l}0.0299 \\
(0.38)\end{array}$ & $\begin{array}{l}-0.0032 * \\
(-1.77)\end{array}$ & $\begin{array}{l}-0.0027 \\
(-1.42)\end{array}$ \\
\hline Scholars & $\begin{array}{l}0.0246 \\
(0.45)\end{array}$ & $\begin{array}{l}0.0402 \\
(0.66)\end{array}$ & $\begin{array}{l}0.0926 \\
(0.58)\end{array}$ & $\begin{array}{l}0.0851 \\
(0.52)\end{array}$ & $\begin{array}{l}0.0009 \\
(0.25)\end{array}$ & $\begin{array}{r}0.0006 \\
(0.17)\end{array}$ \\
\hline Accountants & $\begin{array}{l}0.1167 \\
(1.54)\end{array}$ & $\begin{array}{l}0.1401 * \\
(1,64)\end{array}$ & $\begin{array}{l}0.0397 \\
(0.18)\end{array}$ & $\begin{array}{l}-0.1378 \\
(-0.60)\end{array}$ & $\begin{array}{l}0.0097 * \\
(1.88)\end{array}$ & $\begin{array}{l}0.0093 * \\
(1.68)\end{array}$ \\
\hline $\begin{array}{l}\text { Retired government } \\
\text { officials }\end{array}$ & $\begin{array}{l}0.0404 \\
(0.55)\end{array}$ & $\begin{array}{l}0.8719 \\
(1.04)\end{array}$ & $\begin{array}{l}-0.0953 \\
(-0.44)\end{array}$ & $\begin{array}{l}-0.0633 \\
(-0.28)\end{array}$ & $\begin{array}{l}0.0092 * \\
(1.83)\end{array}$ & $\begin{array}{l}0.0103^{*} \\
(1.90)\end{array}$ \\
\hline Current executives & $\begin{array}{l}-0.1157 \\
(-1.62)\end{array}$ & $\begin{array}{l}-0.1122 \\
(-1.41)\end{array}$ & $\begin{array}{l}-0.0085 \\
(-0.04)\end{array}$ & $\begin{array}{l}-0.0476 \\
(-0.22)\end{array}$ & $\begin{array}{l}-0.0040 \\
(-0.81)\end{array}$ & $\begin{array}{l}-0.0016 \\
(-0.30)\end{array}$ \\
\hline Former executives & $\begin{array}{l}-0.0074 \\
(-0.08)\end{array}$ & $\begin{array}{l}0.0407 \\
(0.37)\end{array}$ & $\begin{array}{l}-0.1146 \\
(-0.41)\end{array}$ & $\begin{array}{l}-0.0538 \\
(-0.18)\end{array}$ & $\begin{array}{l}-0.0021 \\
(-0.31)\end{array}$ & $\begin{array}{r}0.0030 \\
(0.41)\end{array}$ \\
\hline Log (firm size) & & $\begin{array}{l}0.0132 \\
(0.01)\end{array}$ & & $\begin{array}{l}0.4544 \\
(0.18)\end{array}$ & & $\begin{array}{l}0.5361 \\
(0.89)\end{array}$ \\
\hline Debt ratio & & $\begin{array}{l}-0.0016 \\
(-0.02)\end{array}$ & & $\begin{array}{l}0.0578 \\
(0.28)\end{array}$ & & $\begin{array}{l}-0.0098 * * \\
(-1.97)\end{array}$ \\
\hline Directory board size & & $\begin{array}{l}-0.0592 \\
(-0.07)\end{array}$ & & $\begin{array}{l}-0.5360 \\
(-0.25)\end{array}$ & & $\begin{array}{l}0.0494 \\
(0.96)\end{array}$ \\
\hline Board independence & & $\begin{array}{l}-0.5291 \\
(-0.03)\end{array}$ & & $\begin{array}{l}-0.7143 \\
(-0.01)\end{array}$ & & $\begin{array}{l}-0.1258 \\
(-1.09)\end{array}$ \\
\hline Supervisory board size & & $\begin{array}{l}-0.1284 \\
(-0.15)\end{array}$ & & $\begin{array}{l}-3.7084 \\
(-1.58)\end{array}$ & & $\begin{array}{l}-0.0210 \\
(-0.39)\end{array}$ \\
\hline $\begin{array}{l}\text { Largest shareholder is } \\
\text { state }\end{array}$ & & $\begin{array}{l}-2.0006 \\
(-0.64)\end{array}$ & & $\begin{array}{l}-2.5101 \\
(-0.30)\end{array}$ & & $\begin{array}{l}0.1526 \\
(0.75)\end{array}$ \\
\hline $\begin{array}{lr}\text { Top } 5 & \text { shareholders } \\
\text { include } \\
\text { shareholders }\end{array}$ & & $\begin{array}{l}-3.0870 \\
(-0.93)\end{array}$ & & $\begin{array}{l}-3.0015 \\
(-0.34)\end{array}$ & & $\begin{array}{l}-0.2573 \\
(-0.12)\end{array}$ \\
\hline _cons & $\begin{array}{l}-71.9854 \\
(-0.84)\end{array}$ & $\begin{array}{l}-60.0715 \\
(-0.64)\end{array}$ & $\begin{array}{l}49.1811 \\
(0.20)\end{array}$ & $\begin{array}{l}141.2771 \\
(0.56)\end{array}$ & $\begin{array}{l}-7.8506 \\
(-1.35)\end{array}$ & $\begin{array}{l}-6.5049 \\
(-1.07)\end{array}$ \\
\hline Industry & & included & & included & & included \\
\hline Number of obs. & 151 & 147 & 146 & 142 & 151 & 147 \\
\hline Prob. $>$ F & 0.0086 & 0.1354 & 0.6262 & 0.8912 & 0.0338 & 0.1820 \\
\hline $\mathrm{R} 2$ & 0.1216 & 0.1706 & 0.0369 & 0.2026 & 0.0991 & 0.2165 \\
\hline Root MSE & 13.012 & 13.58 & 36.839 & 36.144 & 0.8850 & 0.8822 \\
\hline
\end{tabular}

Note: Six models are designed to test the hypotheses. Models 1, 3, 5 are without additional control variables while models 2, 4, 6 include them. Stata makes a F-test with nine industries such that it does not provide the coefficient of industry. The t-statistics are in parentheses. $* * *, * *$ and $*$ denote significance at $0.01,0.05$ and 0.10 levels (two-tailed). 
Table 8. Effects of Characteristics of Supervisory Board Members on Firm Performance

\begin{tabular}{|c|c|c|c|c|c|c|}
\hline \multirow{3}{*}{ Independent variables } & \multicolumn{6}{|c|}{ Dependent variables (for supervisory board members) } \\
\hline & \multicolumn{2}{|l|}{ ROE } & \multicolumn{2}{|l|}{ Rtn } & \multicolumn{2}{|l|}{ EPS } \\
\hline & Model 1 & Model 2 & Model 3 & Model 4 & Model 5 & Model 6 \\
\hline Age & $\begin{array}{l}-0.9177 \\
(-0.29)\end{array}$ & $\begin{array}{l}0.6328 \\
(0.17)\end{array}$ & $\begin{array}{l}0.0768 \\
(0.01)\end{array}$ & $\begin{array}{l}3.4619 \\
(0.35)\end{array}$ & $\begin{array}{l}0.1357 \\
(0.63)\end{array}$ & $\begin{array}{l}0.0490 \\
(0.21)\end{array}$ \\
\hline $\mathrm{Age}^{2}$ & $\begin{array}{l}0.0093 \\
(0.28)\end{array}$ & $\begin{array}{l}-0.0059 \\
(-0.15)\end{array}$ & $\begin{array}{l}-0.0102 \\
(-0.11)\end{array}$ & $\begin{array}{l}-0.0409 \\
(-0.40)\end{array}$ & $\begin{array}{l}-0.0013 \\
(-0.59)\end{array}$ & $\begin{array}{l}-0.0005 \\
(-0.22)\end{array}$ \\
\hline Current executives & $\begin{array}{l}0.0068 \\
(0.16)\end{array}$ & $\begin{array}{l}0.0007 \\
(0.01)\end{array}$ & $\begin{array}{l}0.0247 \\
(0.21)\end{array}$ & $\begin{array}{l}-0.0273 \\
(-0.20)\end{array}$ & $\begin{array}{l}-0.0009 \\
(-0.32)\end{array}$ & $\begin{array}{l}-0.0014 \\
(-0.45)\end{array}$ \\
\hline Accountants & $\begin{array}{l}0.0650 \\
(1.01)\end{array}$ & $\begin{array}{l}0.0483 \\
(0.67)\end{array}$ & $\begin{array}{l}-0.0968 \\
(-0.54)\end{array}$ & $\begin{array}{l}-0.1617 \\
(-0.84)\end{array}$ & $\begin{array}{l}0.0042 \\
(0.95)\end{array}$ & $\begin{array}{l}0.0029 \\
(0.64)\end{array}$ \\
\hline $\begin{array}{l}\text { Retired government } \\
\text { officials }\end{array}$ & $\begin{array}{l}-0.1604 \\
(-1.22)\end{array}$ & $\begin{array}{l}-0.2500^{*} \\
(-1.71)\end{array}$ & $\begin{array}{l}0.4466 \\
(1.23)\end{array}$ & $\begin{array}{l}0.4748 \\
(1.23)\end{array}$ & $\begin{array}{l}-0.0097 \\
(-1.08)\end{array}$ & $\begin{array}{l}-0.0173 * \\
(-1.85)\end{array}$ \\
\hline Former executives & $\begin{array}{l}-0.0098 \\
(-0.07)\end{array}$ & $\begin{array}{l}-0.0555 \\
(-0.36)\end{array}$ & $\begin{array}{l}-0.5034 \\
(-1.36)\end{array}$ & $\begin{array}{l}-0.8855^{* *} \\
(-2.17)\end{array}$ & $\begin{array}{l}-0.0055 \\
(-0.60)\end{array}$ & $\begin{array}{l}-0.0096 \\
(-0.98)\end{array}$ \\
\hline Scholars & $\begin{array}{l}-0.4756 * * \\
(-2.34)\end{array}$ & $\begin{array}{l}-0.4812 * * \\
(-2.19)\end{array}$ & $\begin{array}{l}-0.2143 \\
(-0.39)\end{array}$ & $\begin{array}{l}-0.2800 \\
(-0.48)\end{array}$ & $\begin{array}{l}-0.0193 \\
(-1.40)\end{array}$ & $\begin{array}{l}-0.0174 \\
(-1.24)\end{array}$ \\
\hline Log (firm size) & & $\begin{array}{l}-0.1879 \\
(0.18)\end{array}$ & & $\begin{array}{l}0.7488 \\
(0.28)\end{array}$ & & $\begin{array}{l}0.0852 \\
(1.33)\end{array}$ \\
\hline Debt ratio & & $\begin{array}{l}-0.0135 \\
(-0,17)\end{array}$ & & $\begin{array}{l}0.0855 \\
(0.41)\end{array}$ & & $\begin{array}{l}-0.0097^{* *} \\
(-1.97)\end{array}$ \\
\hline Directory board size & & $\begin{array}{l}0.8254 \\
(1.09)\end{array}$ & & $\begin{array}{l}0.3938 \\
(0.19)\end{array}$ & & $\begin{array}{l}0.0671 \\
(1.40)\end{array}$ \\
\hline Board independence & & $\begin{array}{l}-2.5771 \\
(-1.05)\end{array}$ & & $\begin{array}{l}-5.2421 \\
(-0.14)\end{array}$ & & $\begin{array}{l}-0.1882 * \\
(-1.72)\end{array}$ \\
\hline $\begin{array}{l}\text { Supervisory board } \\
\text { size }\end{array}$ & & $\begin{array}{l}0.1191 \\
(0.14)\end{array}$ & & $\begin{array}{l}-1.0780 \\
(-0.47)\end{array}$ & & $\begin{array}{l}-0.0105 \\
(-0.19)\end{array}$ \\
\hline $\begin{array}{l}\text { Largest shareholder is } \\
\text { state }\end{array}$ & & $\begin{array}{l}1.0394 \\
(-0.30)\end{array}$ & & $\begin{array}{l}-0.1346 \\
(-0.01)\end{array}$ & & $\begin{array}{l}0.2295 \\
(1.05)\end{array}$ \\
\hline $\begin{array}{lr}\text { Top } 5 & \text { shareholders } \\
\text { include } & \text { foreign } \\
\text { shareholders } & \end{array}$ & & $\begin{array}{l}-3.2439 \\
(-0.93)\end{array}$ & & $\begin{array}{l}-2.0051 \\
(-0.21)\end{array}$ & & $\begin{array}{l}0.0039 \\
(0.02)\end{array}$ \\
\hline -cons & $\begin{array}{l}39.1993 \\
(0.52)\end{array}$ & $\begin{array}{l}1.9258 \\
(0.02)\end{array}$ & $\begin{array}{l}22.9964 \\
(0.11)\end{array}$ & $\begin{array}{l}-54.2053 \\
(-0.23)\end{array}$ & $\begin{array}{l}-2.6604 \\
(-0.52)\end{array}$ & $\begin{array}{l}-0.5802 \\
(-0.11)\end{array}$ \\
\hline Industry & & included & & included & & included \\
\hline Number of obs. & 151 & 147 & 146 & 142 & 151 & 147 \\
\hline Prob. > F & 0.2453 & 0.5284 & 0.6076 & 0.71719 & 0.5986 & 0.2866 \\
\hline $\mathrm{R} 2$ & 0.0607 & 0.1252 & 0.0379 & 0.1660 & 0.0371 & 0.2035 \\
\hline Root MSE & 13.456 & 13.947 & 36.819 & 36.785 & 0.9149 & 0.8895 \\
\hline
\end{tabular}

Note: Six models are designed to test the hypotheses. Models 1, 3, 5 are without additional control variables while models 2, 4, 6 include them. Stata makes a F-test with nine industries such that it does not provide the coefficient of industry. The t-statistics are in parentheses. $* * *, * *$ and $*$ denote significance at $0.01,0.05$ and 0.10 levels (two-tailed). Therefore, in China's situation the empirical results might be reasonable. On the one hand, in China's special situation 
underlying political causes should be considered. For example, in some state-owned listed firms the government authority SASAC also has great power in nominating the members of the directory and supervisory board. In this case there would be other more important selecting standards than considering the professional backgrounds or age. As a result, the characteristics of independent directors and supervisory board members might affect firm performance less. On the other hand, most studies on Chinese independent directors or on supervisory boards insist that these are more or less only decorations in most occasions (Dahya et al., 2001, Bai, 2004). If independent directors and supervisory boards are ineffective in Chinese listed firms, it means that independent from their professional backgrounds or age independent directors and supervisory board members do not have the authority to affect the decision making process of management. Thus, they cannot really contribute to the firm performance. This is discussed more thoroughly in the next section.

\section{Discussion and Policy Implications}

As previously discussed, many scholars argue that independent directors in Chinese listed firms have failed to play a substantive role in the corporate governance system. This is mainly due to the following considerations. Firstly, the serious insider-control problem in listed firms makes it difficult for independent directors to stay truly independent. Normally, the shareholders choose the independent directors whereas in most Chinese listed firms independent directors are chosen by the management. Under this situation, independent directors tend to compromise to please the management. Secondly, the percentage of independent directors is too low to challenge the inside directors. Whether to take their advice or not does not depend on the institutional constrains but depends on the consciousness of the insiders themselves. Thirdly, in Chinese listed firms, most independent directors are scholars instead of managers. Thus they may not have a full understanding about the business of listed firms. Some of them even work for several listed firms, which scatters their energies. Fourth, there is no sound human resource market for independent directors in China, which means professional independent directors are still scarce resources. Also, most independent directors have not yet built their own reputations. Furthermore, the lack of training mechanism exacerbates the problem. Thus it is possible that independent directors may choose to remain passive.

In China, the establishment of supervisory boards in listed firms is regarded as an innovation of the modern enterprise system. The initial intention was to learn from the experience of the supervisory board in the German and Japanese corporate governance systems. However, the simple adoption of a foreign system does not seem to work due to the following reasons. Firstly, it is difficult for supervisory board members to perform their duties. The Chinese Company Law regulates that at least one third of the supervisory board members have to be employee representative. However, the data show that most of those employee representatives are from senior leaderships of the union and the party affiliations. They may also belong to the senior management in the company, which makes it difficult to conduct self-monitoring. Even if the employee representatives are ordinary employees, they do not dare to supervise their managers or to point out the problems because the management controls their jobs and salaries. Secondly, since independent directors are introduced into listed firms, the functions of the supervisory board have become more and more unclear. Independent directors and some special committees (such as the audit committee) are also given the duties to supervise and advice management. The unclear division of the tasks must create some sort of inefficiency and futility.

It might be possible that some Chinese listed firms recruit independent directors or supervisory board members only to response to or meet the government's requirement of building a modern enterprise system. However, this is against the policy makers' initial intention to improve the corporate governance by introducing independent directors and supervisory boards. In order to change the situation, policy makers should firstly coordinate the functional conflicts between independent directors and the supervisory board. At present, some popular proposals insist that the supervisory board should supervise the financial and audit statements while independent directors should be in charge of strategic advising, nomination and remuneration. It has to be emphasized that all duties have to be clearly defined and divided by law and regulations. Secondly, the independence of the supervisory board should also be improved since insiders are not efficient in monitoring the management. Thirdly, professional training mechanisms of independent directors and supervisory board members could be established to help them improve their sense of duty. Fourthly, an appropriate insurance system should be introduced to protect the rights of independent directors and supervisory board members. Only under this protection they can really challenge the management with little concern for themselves.

However, these measures are only palliatives. The Chinese corporate structure should be simplified instead of adding too many components. At present, independent supervisory board members are also introduced, which only makes the firm structure even more complicated. For example, there will be problems to clarify the relations between independent directors and independent supervisory board members. A better solution is to repeal the overlapping mechanisms and to give the listed firms rights to choose the corporate governance structures that suit their own situations. Only a corporate governance system that is based on firms' demands and those of their shareholders and other important stakeholders can 
be efficient. However, at present, the dominance of big shareholders in Chinese listed firms does not allow the implementation of the suggested solution because the small shareholders' rights cannot be well ensured. Chinese listed firms still need appropriate policy interventions.

This paper has also some other limitations, which could provide some directions for further research. Firstly, this paper only uses the data in the firm year 2011. Further research could use a panel data set to test the robustness of the results. Secondly, all the SSE 180 index companies are quality-listed firms, which do not represent all the listed firms in China. Small and medium-sized listed firms should also be investigated.

\section{References}

Agrawal, A., \& Knoeber, C. R. (2001). Do Some Outside Directors Play a Political Role? Journal of Law and Economics, 44(1), 179-198. http://dx.doi.org/10.1086/320271

Bai, C. E., Liu, Q., Lu, J., Song, F. M., \& Zhang, J. X. (2004). Corporate Governance and Market Valuation in China, Journal of Comparative Economics, 32(4), 599-616. http://dx.doi.org/10.1016/j.jce.2004.07.002

Bantel, K., \& Jackson, S. (1989). Top Management and Innovations in Banking: Does the Composition of the Top Management Team Make a Difference? Strategic Management Journal, 10, 107-124. http://dx.doi.org/10.1002/smj.4250100709

Brickley, J. A., Linck, J. S., \& Coles, J. L. (1999). What Happens to CEOs after They Retire? New Evidence on Career Concerns, Horizon Problems, and CEO Incentives, Journal of Financial Economics, 52(3), 195-221. http://dx.doi.org/10.1016/S0304-405X(99)00012-4

Byrd, D. T., \& Mizruchi, M. S. (2005). Bankers on the Board and the Debt Ratio of Firms, Journal of Corporate Finance, 11(1-2), 129-173. http://dx.doi.org/10.1016/j.jcorpfin.2003.09.002

Choi, J. J., Park, S. W., \& Yoo, S. S. (2007). The Value of Outside Directors: Evidence from Corporate Governance Reform in Korea, Journal of Financial and Quantitative Analysis, 42(4), 941-962. http://dx.doi.org/10.1017/S0022109000003458

Clarke, D. C. (2006). The Independent Director in Chinese Corporate Governance, Delaware Journal of Corporate Law, $31(1), 125-228$.

Dahya, J., Karbhari, Y., Xiao, J. Z., \& Yang, M. (2001). The Supervisory Board in Chinese Listed Companies: Problems, Causes, Consequences and Remedies, Asia Pacific Business Review, 9(2), 118-137. http://dx.doi.org/10.1080/713999187

Erhardt, N. L., Werbel, J. D., \& Shrader, C. B. (2003). Board of Director Diversity and Firm Financial Performance, Corporate Governance, 14(2), 102-111. http://dx.doi.org/10.1111/1467-8683.00011

Fahlenbrach, R. (2009). Shareholder Rights, Boards, and CEO Compensation, Review of Finance, 13(1), 81-113. http://dx.doi.org/10.1093/rof/rfn011

Gantenbein, P., \& Volonte, C. (2012). Director Characteristics and Firm Performance, Working Paper, Faculty of Business and Economics, University of Basel.

Grimm, C., \& Smith, K. (1991). Management and Organizational Change: A Note on the Railroad Industry, Strategic Management Journal, 12, 557-562. http://dx.doi.org/10.1002/smj.4250120708

Hambrick, D., \& Mason, P. (1984). Upper Echelon: The Organization as a Reflection of Its Top Managers, Academy of Management Review, 9, 193-206.

Hillman, A. J., \& Hitt, M. A. (1999). Corporate Political Strategy Formulation: A Model of Approach, Participation and Strategy Decisions, Academy of Management Review, 24(4), 825-842.

Kesner, I. F. (1988). Directors' Characteristics and Committee Membership: An Investigation of Type, Occupation, Tenure, and Gender, Academy of Management Journal, 31(1), 66-84. http://dx.doi.org/10.2307/256498

Kroszner, R. S., \& Strahan, P. E. (2001). Bankers on Boards: Monitoring, Conflicts of Interest, and Lender Liability, Journal of Financial Economics, 62(3), 415-452. http://dx.doi.org/10.1016/S0304-405X(01)00082-4

Liao, J., Young. M. R., \& Sun, Q. (2009). Independent Directors' Characteristics and Performance: Evidence from China, SSRN: http://ssrn.com/abstract=1489088 (retrieved on March 7, 2013).

Liu, J. G., Tu, Q., Liu, M., \& Xiao, Y. (2010). An Empirical Study on the Independence of Supervisory Board of the Chinese Listed Company: A PLS Approach, 2010 International Conference on Artificial Intelligence and Computational Intelligence (AICI), 2, Los Alamitos, CA: 374-378. 
Miwa, Y., \& Ramseyer, J. M. (2005). Who Appoints Them, What Do They Do? Evidence on Outside Directors from Japan, Journal of Economics and Management Strategy, 14(2), 299-337. http://dx.doi.org/10.1111/j.1530-9134.2005.00043.x

OECD (2011). Corporate Governance of Listed Companies in China: Self-Assessment by the China Securities Regulatory Commission, OECD Publishing: http://dx.doi.org/ 10.1787/9789264119208-en (retrieved on December 19, 2013).

Rose, C. (2005). The Composition of Semi-two- tire Corporate Boards and Firm Performance, Corporate Governance: An International Review, 13(5), 691-701.

Shenzhen Stock Exchange (2006). Analysis of the Performance of Duties of Independent Directors, Audit Committees and Remuneration Committees (in Chinese), Shenzhen.

Stearns, L., \& Mizruchi, M. (1993). Board Composition and Corporate Financing: The Impact of Financial Institution Representation on Borrowing, Academy of Management Journal, 36, 603-618. http://dx.doi.org/10.2307/256594

Tan, J. S., Li, W. J., Wu, J. L., \& Liang, Y. (2007). An Analysis of the Characteristics of Chinese Listed Companies' Independent Director System, Frontiers of Business Research in China, 1(3), 456-481. http://dx.doi.org/10.1007/s11782-007-0027-7

Tian, X. G. (2009). Analysis of the Functions of Supervisory Board System in Modern Chinese Companies, International Journal of Law and Management, 51(3), 153-168.

Zajac, E. J., \& Westphal, J. D. (1996). Director Reputation, CEO-board Power, and the Dynamics of Board Interlocks, Administrative Science Quarterly, 41, 507-529. http://dx.doi.org/10.2307/2393940

\section{(cc) EY}

This work is licensed under a Creative Commons Attribution 3.0 License. 